\title{
GPR 3D PROFILE OF THE ADEQUATENESS OF UNDERGROUND DAMS IN A SUB-WATERSHED OF THE BRAZILIAN SEMIARID ${ }^{1}$
}

\author{
ALEXANDRE DE OLIVEIRA LIMA ${ }^{2}$, FRANCISCO PINHEIRO LIMA-FILHO ${ }^{3}$, NILDO DA SILVA DIAS ${ }^{4}$, JOÃO \\ ANDRADE DOS REIS JÚNIOR ${ }^{5}$, ANDERSON DE MEDEIROS SOUSA ${ }^{6}$
}

\begin{abstract}
The conventional method monitoring and adequateness of underground dams requires invasive investigatory actions with in their interior structure and only provides specific information for small volumes. On the contrary, application of non-invasive sensing techniques, such as ground penetrating radar (GPR), makes it possible to investigate and explore underground without affecting their structure. A GRP 3D profile was acquired with the aim to allot and monitor an underground dam in the Brazilian semiarid region in the alluvial sub-watershed of the Riacho Pau Lavrado in the Sertão Central de Lajes region of the state of Rio Grande do Norte in Brazil. The GPR profile records were acquired along an alluvial section, processed using the Reflex 5 software and exported into the Opendetec 4.4.0 software in order to obtain a virtual 3D model. The GPR 3D profile of the alluvial deposits shows irregularities of the crystalline basement and external topographical surface (soil). The interpretation of the alluvial GPR profile allows precise adequateness of the underground dam, which supports an increase in the area of hydric accumulation and promotes low-cost building due to the allocation selected with minor sedimentation.
\end{abstract}

Keywords: Ground-penetrating radar. Water resources. Strategies of coexistence in the semiarid.

\section{PERFIL GPR 3D PARA ALOCAÇÃO DE BARRAGEM SUBTERRÂNEA EM SUB-BACIA DO SEMIÁRIDO BRASILEIRO}

\begin{abstract}
RESUMO - Os métodos de investigação convencionais para alocação e manejo de barragens subterrâneas requerem ações invasivas no interior da estrutura investigadas, fornecendo apenas informações pontuais para pequenos volumes. Já, a aplicação de técnica de detecção não invasiva como, por exemplo, o Ground Penetrating Radar (GPR), possibilita investigar e explorar o sub-superficie sem destruir a estrutura. Com o objetivo de avaliar a inclusão da técnica Ground Penetrating Radar para estudos de alocação e monitoramento de barragens subterrânea no semiárido brasileiro, realizou-se a aquisição de perfil com Ground-Penetrating Radar no corpo aluvionar na sub-bacia do riacho Pau Lavrado, região Sertão Central de Lajes, Estado do Rio Grande do Norte do Brasil. O dados de registro do perfil Ground-Penetrating Radar foram adquiridos ao longo do trecho do corpo aluvionar selecionado, processado no software Reflex 5 e exportadas para o software Opendetec 4.4.0, obtendo-se um modelo virtual 3D do corpo aluvionar. A análise do perfil Ground-Penetrating Radar com modelagem 3D do corpo aluvionar indicaram as irregularidades do embasamento cristalino e da superfície topográfica externa (solo). A interpretação do perfil GPR do corpo aluvionar permitiu a alocação precisa da barragem subterrânea, aumentando a sua área de acumulação hídrica com custo construtivo reduzido devido à escolha de locais com menores pacotes sedimentares.
\end{abstract}

Palavras-chave: Radar de penetração no solo. Recursos hídricos. Convivência com o semiárido.

\footnotetext{
${ }^{*}$ Corresponding author

${ }^{1}$ Received for publication in $01 / 17 / 2017$; accepted in $05 / 29 / 2017$.

Paper extracted from the doctoral thesis of the first author.

${ }^{2}$ Departmnent of Environmental Management, Universidade do Estado do Rio Grande do Norte, Mossoró, RN, Brazil; alexandrelimarn@gmail.com.

${ }^{3}$ Department of Geology, Universidade Federal do Rio Grande do Norte, Natal, RN, Brazil; pinheiro@geologia.ufrn.br

${ }^{4}$ Center of Agrarian Sciences, Universidade Federal Rural do Semi-Árido, Mossoró, RN, Brazil; nildo@ufersa.edu.br.

${ }^{5}$ Department of Agrarian Sciences, Universidade Federal Rural da Amazônia, Parauapebas, PA, Brazil; junioreis03@yahoo.com.br.

${ }^{6}$ Instituto Nacional de Colonização e Reforma Agrária, Natal, RN, Brazil; anderson.souza@ifpb.edu.br.
} 


\section{INTRODUCTION}

The availability of adequate water of sufficient quality has become a limiting factor for development (SHADEED; LANGE, 2010). In arid and semiarid regions, where surface water resources are very scarce or even non-existent, groundwater is the only available water resource. As a consequence, greater attention is being placed on how to manage groundwater without causing unacceptable environmental, economic, or social consequences (ONDER; YILMAZ, 2005; RAJU; REDDY; MUNIRATHNAM, 2006; ERTSEN; HUT, 2008).

In arid and semiarid regions, rainwater harvesting has been used for many years to provide water for agricultural and domestic uses and a number of low-cost building and maintenance technologies developed in these regions make rainwater storage possible for human and animal consumption, as well as agricultural use. Underground dams stand out as one of such alternative technologies directed for semiarid regions with great potential to supply the water demand of families living in rural communities (LIMA et al., 2013; LOPES et al., 2013). In order to store water in the sub-surface, underground dams can be constructed in alluvial rivers and intermittent streams under dry conditions.

The technology of sub-surface water storage is used around the world in order to supply the water demand for human and animal consumption, as well as small agricultural operations (QUILIS et al., 2009; FORZIERI et al., 2008; EL-HAMES, 2011; SENTHILKUMAR; ELANGO, 2011). In Brazil, there are reports of its use from as early as the 19th century. Nevertheless, there are few technical studies and research about the adequateness, construction, and management of underground dams (LIMA et al., 2013).

Ground penetrating radar (GPR) is a type of geophysical imaging equipment, known as Georadar, which can be useful in the construction of underground dams in regards to the precision of allocation, monitoring, and management. The Georadar associated with geo-referencing of an external surface by means of a Global Positions System (GPS) allows the development of 3D images of shallow subsurface $(<50 \mathrm{~m})$ by modeling the soil profile with high quality and centimeter accuracy, as well as providing a decision-making tool for the construction of underground dams.

According to Castro et al. (2014), the application of techniques for the acquisition, processing, and interpretation of GPR data acquired in two orthogonal directions illustrates the advantages of 3D surveys in the detection and imaging of buried targets and depositional features. Although there are currently no reports of the accuracy of Georadar technique for the adequate construction of dams, this technique is widely used for imaging alluvial areas (BOWLING et al., 2005; GAUW et al., 2006), which reinforces the possibility of using GPR in the sustainable water storage technology of arid and semiarid zones.

In this paper we describe the application of 3D GPR technologies for the adequateness of one underground dam that will be built in the alluvial sub-watershed of the Riacho Pau Lavrado in the state of Rio Grande Norte state within the Brazilian semiarid region. The investigation aims to detect and localize the smaller thickness of sediment associated greater water storage capacities in the alluvial sub-watershed that are potential ways of reducing the costs of dam construction.

\section{MATERIAL AND METHODS}

The acquisition of a 3D GPR profile was carried out in the alluvial sub-watershed of the Riacho Pau Lavrad in the region of the Sertão Central de Lajes region in the state of Rio Grande do Norte state in Brazil (Figure 1). The geology of the study area is characterized by the presence of unconsolidated Quaternary siliciclastic material, in addition to products of the crystalline basement weathering (metamorphic rocks) that outcrop and are subsequently washed away and deposited in riverbeds, which characterizes the intermittent network drainage of these areas.

Five allocation points $\left(\mathrm{BS}_{1}, \mathrm{BS}_{2}, \mathrm{BS}_{3}, \mathrm{BS}_{4}\right.$ and $\mathrm{BS}_{5}$ ) of the underground dam were chosen along the alluvial sub-watershed of the Riacho Pau Lavrado. These allocation points were previously chosen utilizing satellite imagery, taking into account community decisions regarding potential construction locations, and later visited. Pints were then chosen using both traditional and geophysical allocation criteria.

The traditional allocation criteria used were proposed by Costa (2004) and include: a) minor side extensions; b) maximum sedimentary thickness $(1.5 \mathrm{~m})$; and $\mathrm{c})$ hydric demand required by farmers. Through a combination of the allocation criteria provided by geophysical imaging, the allocation of the dam was demarcated following the interpretation of the alluvial image by means of the non-invasive geophysical method, 3D GPR, as described by Lima (2012) 


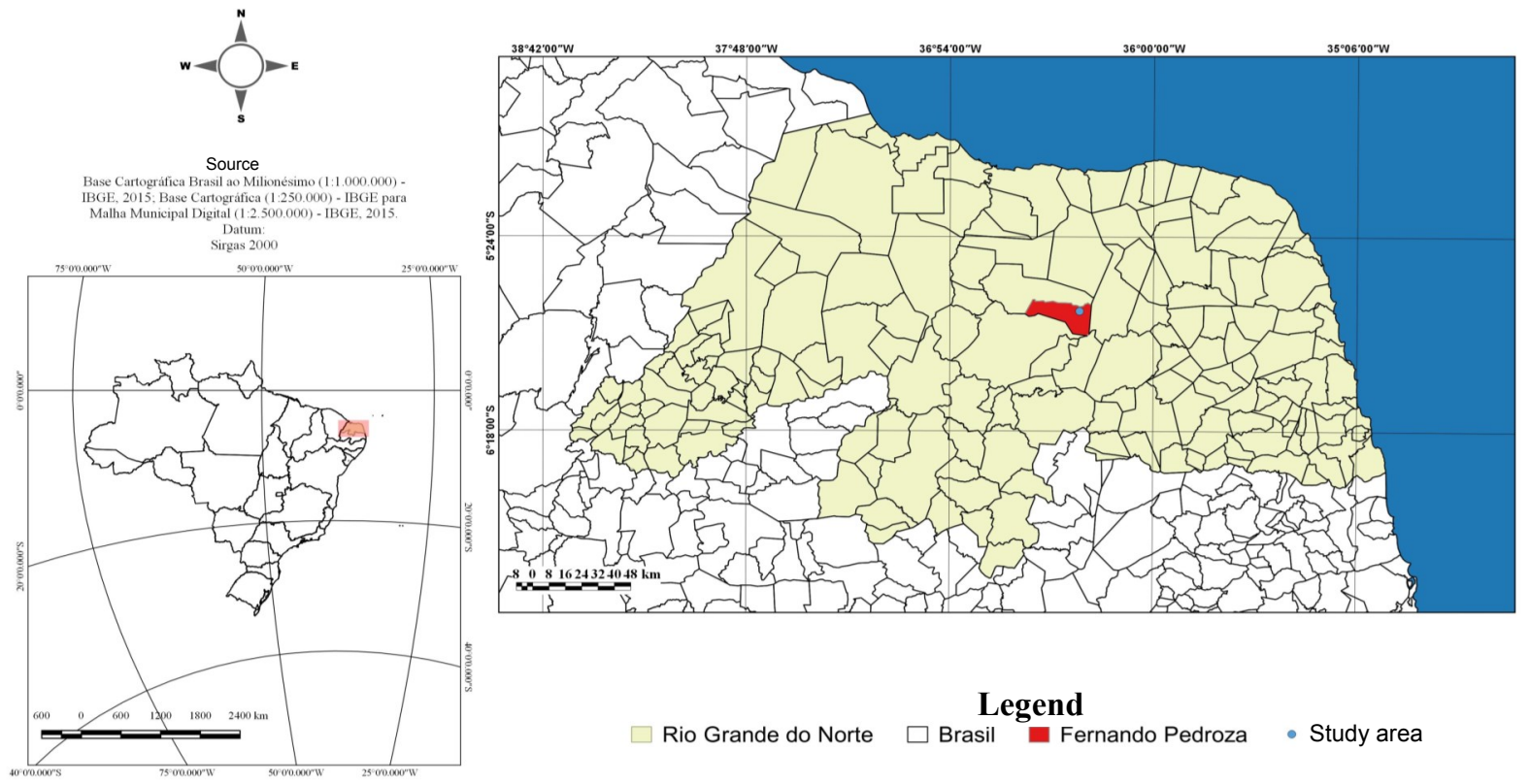

Figure 1. Geographic localization of the region of Sertão Central de Lajes in the state of Rio Grande do Norte, Brazil. (Google Maps, 2012).

In this study, the GPR model Sir 3000 of the Geological Survey Inc. (GSSI) was employed. In such a device, the antennas are shielded and use resistant connectors and coated/sealed electronic boards. The shielding structure aims to eliminate interference generated on the ground and operates at temperatures between 20 and $50{ }^{\circ} \mathrm{C}$. Because the aims of the present study included acquisition of an image of the crossing point between the basement and sediment, the GPR device was connected to a central antenna with high frequency and high resolution $(200 \mathrm{MHz}$ and $400 \mathrm{MHz}$ ). The Reflex 5.0 software was used for the processing and interpretation of radargrams.

Imaging of the alluvium and allocation of underground dams with GPR followed a series of steps. First, the GPR section was zero-time corrected, and the direct waves and low- and high-frequency noises were removed. Effects related to the electromagnetic induction and signal attenuation at depth were then corrected. Finally, the reflectors were repositioned using the time-to-depth conversion. Once processed, the data were converted to the SEG-Y format and later imported into the OpendTect software for 3D visualization and construction of a 3D model of the alluvial region.

\section{Elaboration of introductory grid for GRP use}

A section of the stream on which the underground dam was intended to be built, following indication of community farmers, was selected for study. Such indication is mostly related to the proximity of the residential community, in the case the dam would be used for human consumption. Alternatively, in the case where the dam is for agricultural production, its location should be near to agricultural soils. After selecting the area to be imaged, a rectangular grid was demarcated that formed lines perpendicular and parallel to the river channel. This procedure took place using at least two central lines positioned longitudinally in the direction of flow. One of these lines was positioned following the riverbed near its thalweg. The perpendicular lines were spaced at $10 \mathrm{~m}$ closest to and $30 \mathrm{~m}$ farthest from the allocation field (Figure 2).

\section{Density of the grid}

The density of the grid from the selected location was chosen in order to obtain information regarding the complex and detailed manner of the alluvial features and irregularities of the basement. At this stage, the number of lines transversal to stream flow and the spacing between them was defined based on the gradient of the river, alluvial thickness, and fractural basement. When possible, the GPR lines perpendicular to the stream flow began in the crystalline outcrop beside the river or stream and ran until the outcrop on the opposite side (Figure 3). This choice aimed to visualize the most clear and sharp reflections in the contact between sediment and basement along the GPR line (NAKASHIMA; ZHOU, 2001). 


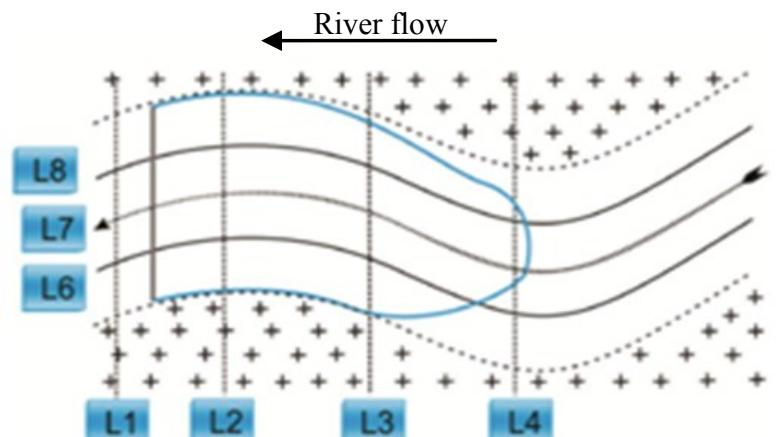

Hydraulic basin area

Ln GPR line

Figure 2. Schematic diagram of the GPR grid and initial allocation of underground dams from the sub-washed sections of the Pau Lavrado stream.

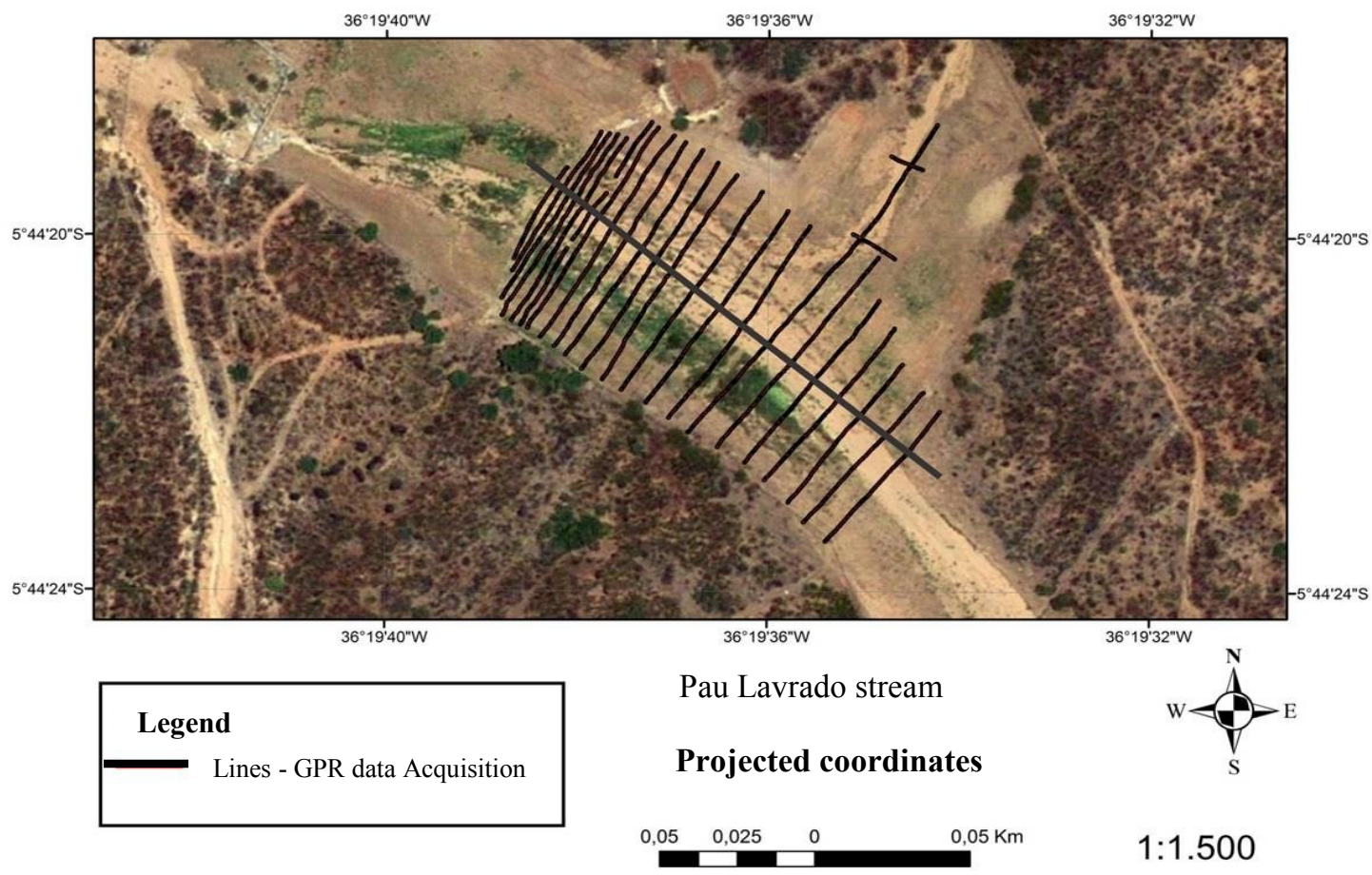

Figure 3. Grid of the GPR line used to choose the allocation points of the underground dams in the sub-watershed sections of the Pau Lavrado stream.

All GPR lines were built and geo-referenced using the geodesic GPS with dual receivers (base and rover) and dual frequency (L1-L2) using the Hyper Life + model. Following this procedure, it was possible to obtain the topographic correction and external geometry of the surface.

It is important to mention that the irregularity of the basement is an important criterion for defining the amalgamation of GPR lines. For example, intense basement irregularities should be characterized by more compact GPR grid lines. This characteristic can be evaluated by the existence of the outcropping dikes that interrupt stream flow. Another feature is the presence of fractures and foliations that may contribute to the existence of water infiltration that feeds the fissure aquifer and causes major water loss. Such features could be identified with the construction of the underground dam. This characteristic can be evaluated by existing geological maps. As a result, such criteria are evaluated in an integrated way, which allows the realization of a GPR grid with regard to the appropriate interpretation of the irregularities observed in the contact, sediments, and basement.

\section{RESULTS AND DISCUSSION}

The five points chosen along the alluvial sub-watershed for allocation of the underground 
dams using geophysical, traditional, and satellite imagery methods are shown in Figure 4. The $\mathrm{BS}_{3}$ underground dam shows a high correspondence between the allocation previously completed in the office and the field allocation when compared with non-invasive sensing techniques (GPR).

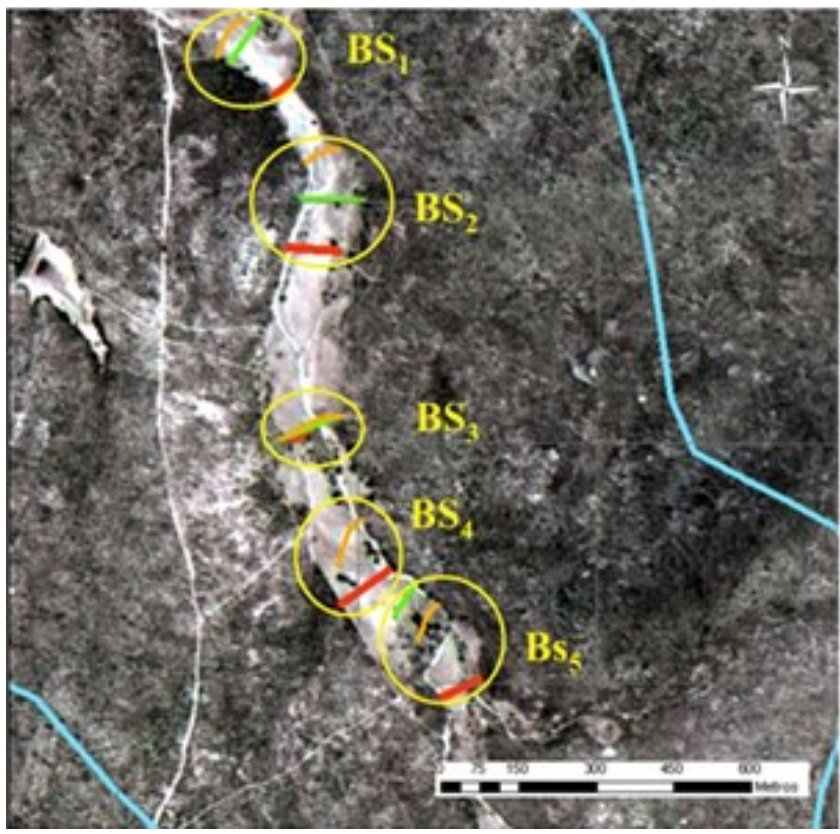

Legend

Allocating criterion of the underground dam:

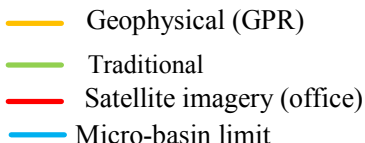

Figure 4. Points chosen along the alluvial sub-watershed for allocation of the underground dams using geophysical, traditional, and satellite imagery methods. The image source is SPOT with $2.5 \mathrm{~m}$ spatial resolution.

The radargram was described with the conventional method of a cross-section of the river channel. The contact between the alluvium and impermeable basement was observed at two depocenters of 3 and $4.5 \mathrm{~m}$ (Figure $5 \mathrm{~A}$ ). The alluvial volume was estimated from two wells drilled in the depocenters (Figure 5B). The overestimated volume was generated from two wells located in shallower parts of the basement (Figure 5C), and the underestimated volume was generated from three wells shown in Figure 5D. The closest approach of the alluvium irregularities and, consequently, the best estimate of its volume is shown in Figure 5E. We could infer that the invasive methods are insufficient because they generated specific results and could not express the irregularities of the basement and existence of paleochannels.

Figure 6 shows the allocation of the underground dam in point $\mathrm{BS}_{1}$, which is adequate following the traditional (A) and GPR method (B). After processing and interpretation of the radargram, the allocation of the interception was repositioned $25 \mathrm{~m}$ downstream. Such modification promoted an increase of accumulation capacity of the water volume, in addition to a reduction of the excavation cost.

The financial planning tool of the project's hydro-environment is based on information of the internal characteristics of the alluvial region. In this perspective, the costs are related to the estimated number of machine hours required to excavate across the dike using a backhoe. There are no engineering operations associated in the construction of the underground dam except for the excavation activity, where the cost can be more than $80 \%$ of the total building value (COSTA, 2004). In fact, the GPR method promoted a low number of machine hours for excavation because it allowed detection and localization of smaller sediment thickness associated with greater water storage capacities in the alluvial sub-watershed, which are potential ways of reducing the costs of dam construction. 


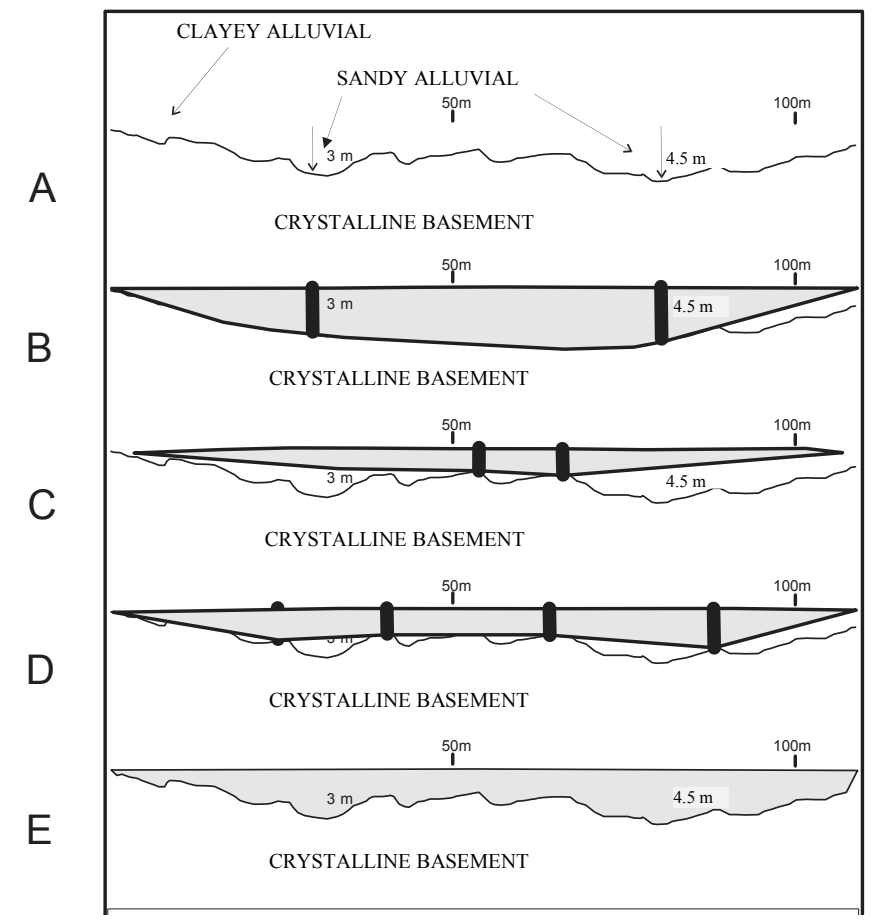

Figure 5. Cross-section radargrams of the river channel following criteria by Costa (2004).
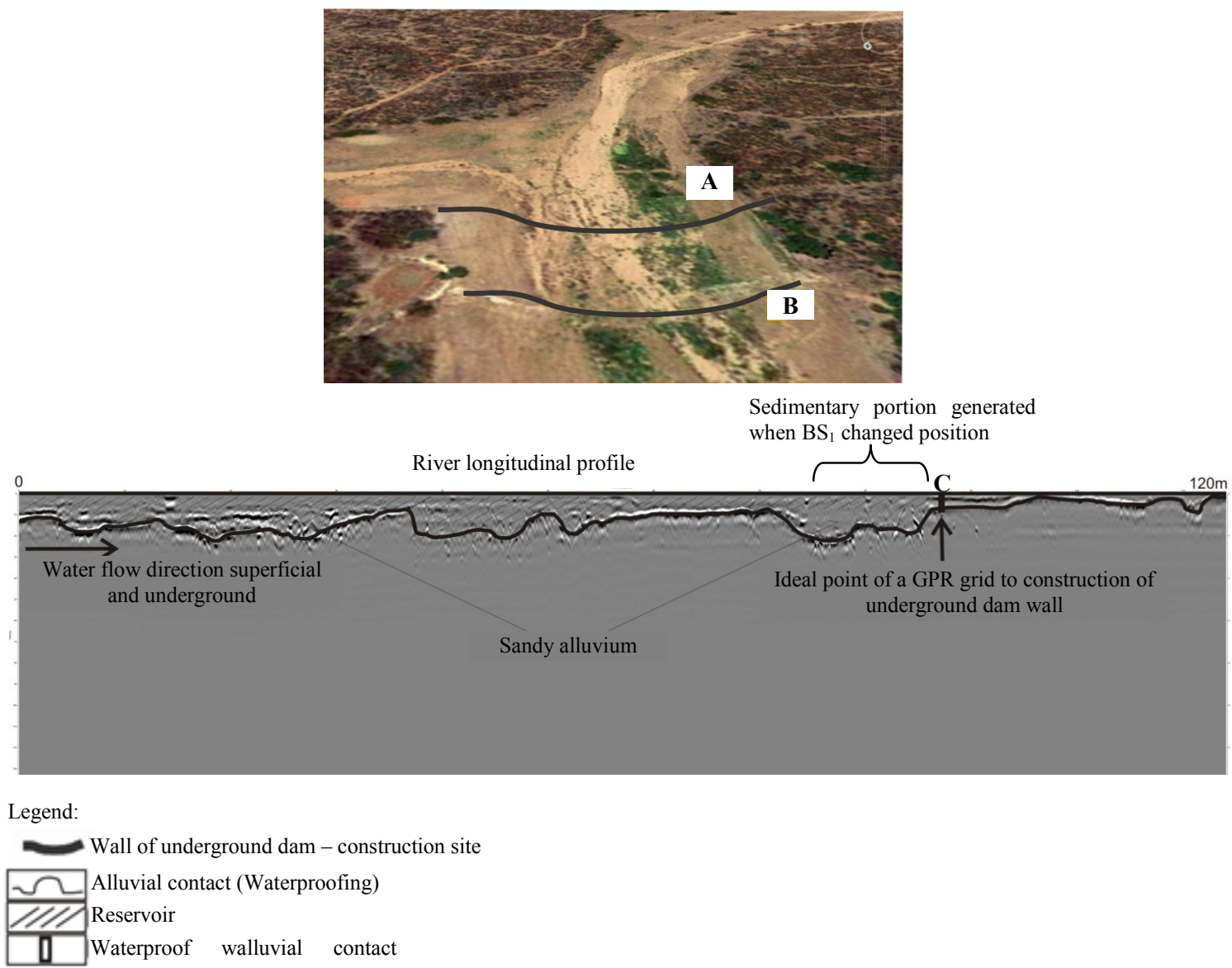

Figure 6. The allocation of the underground dam $\mathrm{BS}_{1}$ using (A) traditional and (B) geophysical (GPR) methods, and (C) schematic diagram of the river's longitudinal profile with the GPR grid positionings indicated for construction of the underground dam wall. 
According to Nakashima and Zhou (2001), the GPR method detects the presence of groundwater from multiple and ambiguous reflectors at a depth about $8 \mathrm{~m}$, which provides recognition of the existence of underground water and determination of its depth (i.e. water level). Such information is essential for the financial planning associated with use of GPR technology. Water generates a reflection with extreme power relative to the decrease of the electromagnetic wave velocity, as well as a difference of dielectric properties of fluids relative to other materials (NOBES; FERGUSON; BRIERLEY, 2001).

We have systematized the GPR imaging results, subsequent interpretations, and $3 \mathrm{D}$ virtual
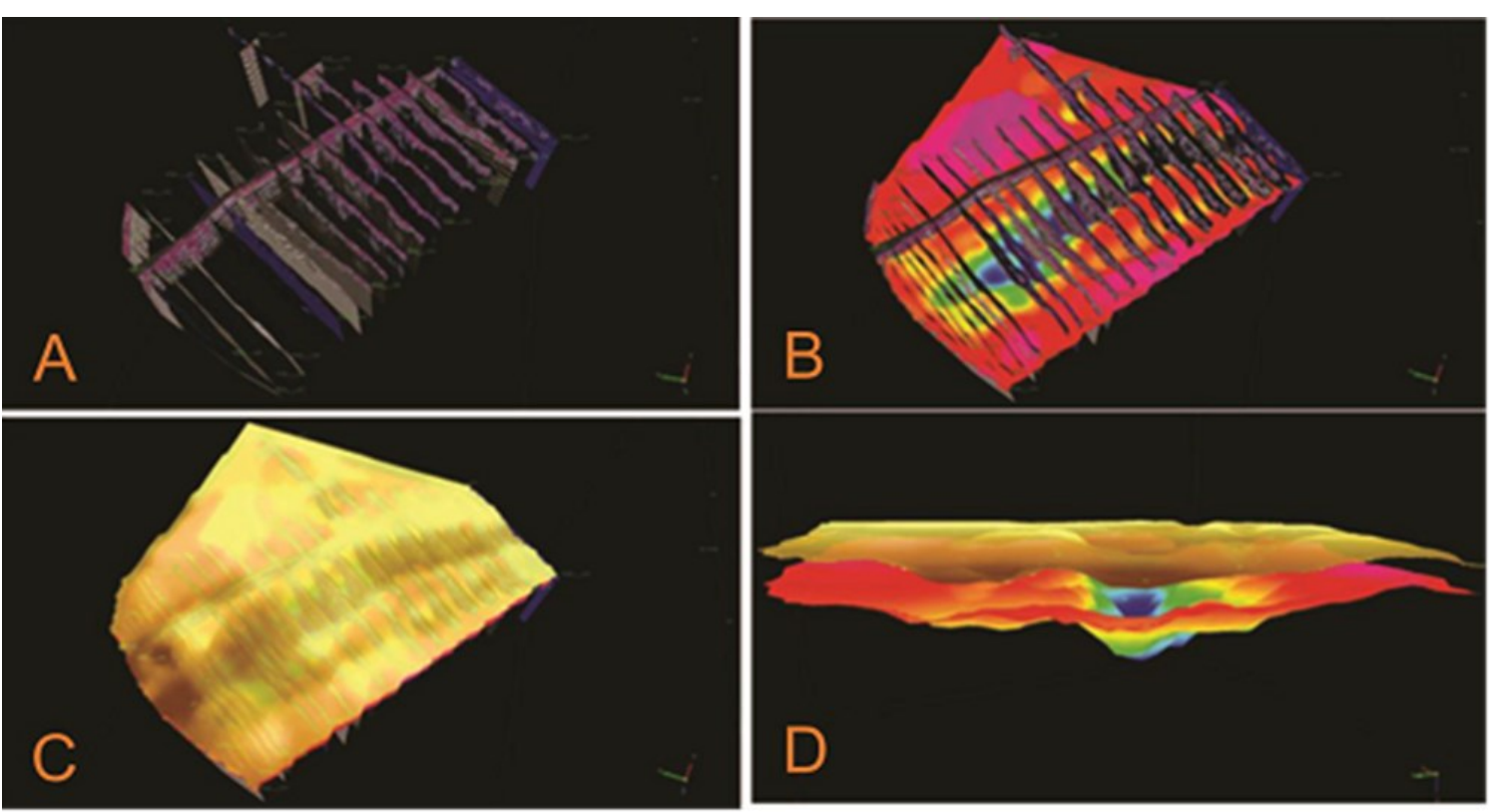

Figure 7. Virtual 3D model of the alluvial section from the sub-watershed of the Pau Lavrado stream.

The entire area of the reservoir basin was imaged, which provided a complete view of the irregularities of the basement and its contact with the overlying sedimentary layer. The 3D virtual imaging of alluvium indicates that the location selected, according to traditional methods (letter A of Figure 8 ), was not the most appropriate and the impermeable septum was therefore relocated 25 meters downstream ( $A^{\prime}$ in Figure 8). This adjustment, generated by the virtual $3 \mathrm{D}$ model evaluation, decreased the excavation costs due to the indication that the new location should be at a shallower depth, in addition to generating an increased area of water accumulation within the hydraulics of $\mathrm{BS}_{1}$

The internal geometry of the GPR-imaged alluvium effectively contributed to the identification modeling acquired from $\mathrm{BS}_{1}$. The radargrams were processed and interpreted, as shown in Figure 7A. The contour of the crystalline basement was subsequently generated from the GPR grid (Figure 7B). The external surface of the alluvium, corresponding to the level of alluvial deposits, was also generated with the interpretation of the GPR grid (Figure 7C). Finally, the front base and topography of the area were imaged (Figure 7D). Such modeling generated a topographic surface that corresponds to the ground level and basement of the selected area, which permitted the positioning of the impermeable septum to allow a high water volume accumulation capacity in the reservoir.

of the best reservoirs along the river basin, which has consequently optimized the work of the BS allocation. Similarly, Gauw et al. (2006) found satisfactory results when using GPR in the alluvial deposits of the Assu River, also in the state of Rio Grande do Norte (Brazil), with the purpose of characterizing both the internal and external the geometry and elaborating on a deterministic 3D virtual model

Although the GPR method has shown optimistic results for this type of application, it also presents some limitations. Tye et al. (2011) also reported the importance of geophysical surveys for geological mapping of alluvial bodies and the development of the 3D geological models, which contribute to the knowledge of the complexity of sedimentary environments, such as alluvial deposits. 


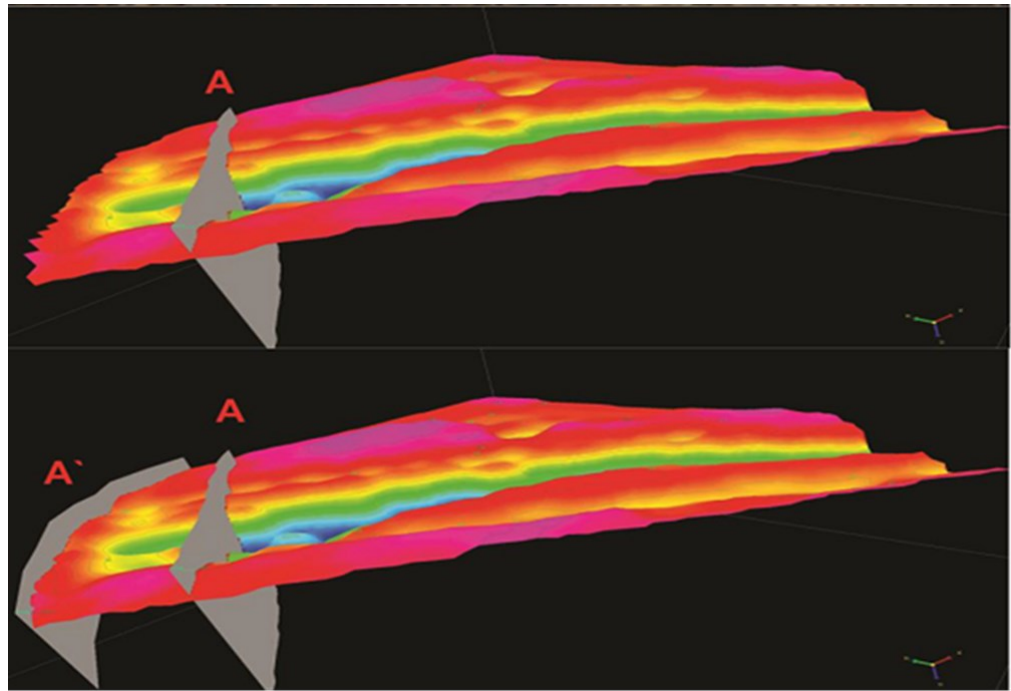

Figure 8. Interception point of $\mathrm{BS}_{1}$ allocated by traditional methods (A) and the new location suitable for construction of the underground dam's impermeable septum (A') shifted following the 3D modeling of the alluvial.

Loperte et al. (2011) demonstrated that GPR can be a useful tool for the non-intrusive diagnostics of dams and encouraged its use for other defect typologies affecting dams, such as waterproof layer fractures, detachment, and concentrated water infiltration zones. The authors add that the primary limitation encountered is that the spatial resolution is not always adequate to resolve each sandstone layer. As such, only large sections that may host the desired layer can be detected. According to Castro et al. (2014), one of the technical limitations of GPR is the local physical characteristics, such as electromagnetic properties, because sandy soil layers containing high levels of clay, moisture and/or salinity compromise the prospection scope due to the fact that the electromagnetic wave energy is highly attenuated, which impedes diffusion to lower layers.

There are a vast amount of authors in the literature who relate the limiting factors for GPR use (e.g. attenuation capacity of the electromagnetic signal emitted by the equipment, (CASSIDY, 2007; LAHOUAR; AL-QADI, 2008). Of these factors, the one that stands out as the most important is the salinity and clay content (ANNAN, 2002).

On the other hand, Jol and Bristow (2003) indicated that GPR can be used in the presence of conductive materials (e.g. clay, silt, and saline water) since the target being detected is relatively superficial or exhibits a great contrast with the surrounding material, as is the case with the contour of the basement. Nonetheless, research should continue to be carried out to test the limits of this method compared to the levels of salts and clays found in the alluviums of the Brazilian semiarid. Thus, it is recommended to test the GPR profile and 3D modeling for the allocation of dams in other parts of Brazilian semiarid alluvial soils in order to evaluate the accuracy of the identification method for layers of thicker clay soils.

\section{CONCLUSIONS}

Inclusion of the 3D GPR tool for the allocation of underground dams in the sub-washed areas of the Riacho Pau Lavrado in the region of Sertão Central de Lajes in the state of Rio Grande do Norte (Brazil) allowed the repositioning of construction sites of underground dams. These changes have led to a decrease in excavation costs and an expansion of water accumulation area within the five built underground dams. The methodology used for imaging of the alluvium with GPR and the later generation of $3 \mathrm{D}$ virtual models is efficient under the conditions studied and constitutes a major innovation for the allocation process of underground dams process.

\section{REFERENCES}

ANNAN, A. P. GPR - History, trends and future developments. Subsurface sensing and application, Nova York, v. 3, n. 4, p. 253-260, 2002.

BOWLING, J. C. et al. Delineating alluvial aquifer heterogeneity using resistivity and GPR data. Ground Water, Westerville, v. 43, n. 6, p. 890-903, 2005.

CASSIDY, N. J. A Review of practical numerical modelling methods for the advanced interpretation of ground-penetrating radar in nearsurface environments. Near Surface Geophysics, Amsterdã, v. 5 , n. 1 , p. 5-21, 2007

CASTRO, D. L. et al. Ground-Penetrating Radar imaging techniques applied in 3D environment: Example in inactive dunes. Revista Brasileira de Geofísica, Rio de Janeiro, v. 32, n. 2, p. 273-289, 
2014.

COSTA, W. D. Barragens subterrâneas: conceitos básicos, aspectos locacionais construtivos. In: CABRAL, J. J. S. et al. (Eds.). Água subterrânea: aquífero costeiro e aluviões, vulnerabilidades e aproveitamento. Recife: Editora Universitária da UFPE, 2004. v. 1, cap. 1 . p. 13-59.

EL-HAMES, A. S. Determination of the transient water table rise behind constructed underground dam. Arabian Journal Geoscince, Riyadh, v. 5, n. 6, p. 1359-1366, 2011.

ERTSEN, M.; HUT, R. Two waterfalls do not hear each other. Sand-storage dams, science and sustainable development in Kenya. Physics and Chemistry of the Earth, Amsterdã, v. 34, n. 1-2, p. 14-22, 2008.

FORZIERI, G. et al. A methodology for the preselection of suitable sites for surface and underground small dams in arid areas: A case study in the region of Kidal, Mali. Physics and Chemistry of the Earth, Amsterdã, v. 33, n. 1-2, p. 74-85, 2008 .

GAUW, D. S. et al. Nova metodologia para aquisição de geometria (interna e externa) de depósitos fluviais recentes e modelagem deterministica 3D: Exemplo do rio Assu. Revista de Geologia, Fortaleza, v. 19, n. 1, p. 49-60, 2006.

JOL, H. M.; BRISTOW, C. S. An introduction to ground penetrating radar (GPR) in sediments. Geological Society, London, v. 211, Sup., p. 1-7, 2003.

LAHOUAR, S.; AL-QADI, I. L. Automatic detection of multiple pavement layers from GPR data. NDT\&E International, Amsterdã, v. 41, n. 1, p. 69-81, 2008.

LIMA, A. O. Nova abordagem metodológica para locação, modelagem 3D e monitoramento de barragens subterrâneas no semiárido brasileiro. 2012. 244 f. Tese (Doutorado em Geodinâmica e Geofísica: Área de Concentração Geodinâmica) Universidade Federal do Rio Grande do Norte, Natal, 2012.

LIMA, A. O. et al. Barragens subterrâneas no semiárido brasileiro: Análise histórica e metodologias de construção. Irriga, Botucatu, v. 18, n. 2, p. 200-211, 2013.

LOPERTE, A. et al. Ground Penetrating Radar in Dam Monitoring: The Test Case of Acerenza (Southern Italy). International Journal of
Geophysics, Cairo, v. 2011, s/n., p. 1-9, 2011.

LOPES, H. L. et al. Mapeamento de áreas aluvionares no semiárido brasileiro por meio de dados colaterais e imagens orbitais. Revista Brasileira de Engenharia Agrícola e Ambiental, Campina Grande, v. 17, n. 7, p. 763-769, 2013.

NAKASHIMA, Y.; ZHOU, H. S. Estimation of groundwater level by GPR in an area with multiple ambiguous reflections. Journal of Applied Geophysics, Amsterdã, v. 47, n. 3-4, p. 241-249, 2001

NOBES, D. C.; FERGUSON, R. J.; BRIERLEY, G. J. Ground-penetration radar and sedimentological analysis of Holocene Floodplains: Insight from the Tuross valley, New South Wales. Australian Journal of Earth Science, North Ryde, v. 48, n. 3, p. 437-355, 2001.

ONDER, H.; YILMAZ, M. Underground Dams: A tool of sustainable development and management of groundwater resources. European water, Tessália, v. 11, n. 12, p. 35-45, 2005.

QUILIS, R. O. et al. Measuring and modeling hydrological processes of sand-storage dams on different spatial scales. Physics and chemistry of the Earth, Amsterdã, v. 34, n. 4-5, p. 289-298, 2009.

RAJU, N. J.; REDDY, T. V. K.; MUNIRATHNAM, P. Subsurface dam to harvesting rainwater. A case study of the Swarnmukhi river basin, Souther India. Hydrogeology Jounal, Hudson, v. 14, n. 4, p. 526$531,2006$.

SENTHILKUMAR, M.; ELANGO, L. Modelling the impact of a subsurface barrier on groundwater flowin the lower Palar River basin, southern India. Hydrogeology Journal, Hudson, v. 19, n. 4, p. 917 928, 2011

SHADEED, S.; LANGE, J. Rainwater harvesting to alleviate water scarcity in dry conditions: A case study in Faria Catchment, Palestine. Water Science and Engineering, Nanjing, v. 3, n. 2, p. 32-143, 2010 .

TYE, A. M. et al. Using integrated near-surface geophysical surveys to aid mapping and interpretation of geology in an alluvial landscape within a 3D soil-geology framework. Near Surface Geophysics, Eindhoven, v. 9, n. 1, p. 15-31, 2011. 